\title{
Influence of different concentrations of disodium fumarate on methane production and fermentation of concentrate feeds by rumen micro-organisms in vitro
}

\author{
M. D. Carro* and M. J. Ranilla \\ Departamento de Producción Animal I, Universidad de León, 24071 León, Spain
}

(Received 27 November 2002 - Revised 16 April 2003 - Accepted 10 May 2003)

\begin{abstract}
Batch cultures of mixed rumen micro-organisms were used to study the effects of different concentrations of disodium fumarate on the fermentation of five concentrate feeds (maize, barley, wheat, sorghum and cassava meal). Rumen contents were collected from four Merino sheep fed lucerne hay ad libitum and supplemented with $300 \mathrm{~g}$ concentrate/d. Disodium fumarate was added to the incubation bottles to achieve final concentrations of $0,4,7$ and $10 \mathrm{~mm}$-fumarate. In $17 \mathrm{~h}$ incubations, the final $\mathrm{pH}$ and total volatile fatty acid production increased $(P<0.001)$ linearly for all substrates as fumarate concentration increased from 0 to $10 \mathrm{~mm}$. Propionate and acetate production increased $(P<0.05)$, while the value of the acetate:propionate ratio decreased $(P<0.05)$ linearly with increasing doses of fumarate. In contrast, L-lactate and $\mathrm{NH}_{3}-\mathrm{N}$ concentrations in the cultures were not affected $(P>0.05)$ by the addition of fumarate. For all substrates, fumarate treatment decreased $(P<0.05) \mathrm{CH}_{4}$ production, the mean values of the decrease being $2 \cdot 3,3 \cdot 8$ and $4.8 \%$ for concentrations of 4,7 and $10 \mathrm{~mm}$-fumarate respectively. Addition of fumarate did not affect $(P>0.05)$ the total gas production. If the results of the present experiment are confirmed in vivo, fumarate could be used as a feed additive for ruminant animals fed high proportions of cereal grains, because it increased $\mathrm{pH}$, acetate and propionate production and it decreased $\mathrm{CH}_{4}$ production.
\end{abstract}

Batch cultures: Concentrate feeds: Fumarate: Rumen

High-producing ruminant animals are usually fed high amounts of concentrates. However, negative effects are often observed (Mould, 1988; Carro et al. 2000) with diets containing high levels of concentrates (decrease in rumen $\mathrm{pH}$, inhibition of fibre degradation, accumulation of lactic acid, etc.) and therefore antimicrobial compounds are routinely incorporated as feed additives to improve production efficiency. In recent years, there has been increasing concern about the use of antibiotics in animal feeding, and in March 2002 the European Union presented a new proposal that would phase out the authorizations for the four antibiotics being used as growth promoters in animal feed in the European market by January 2006. As a consequence, there is an urgent need for the development of alternatives to the use of these feed additives. Some authors (Callaway \& Martin, 1996; Newbold et al. 1996) have suggested that organic acids (aspartate, fumarate, malate) may provide an alternative to currently used antibiotic compounds in animals fed high proportions of concentrates.

Nisbet \& Martin (1990) showed that the growth of Selenomonas ruminantium HD4 in a medium that contained lactate was stimulated approximately twofold by $10 \mathrm{~mm}-\mathrm{L}$-aspartate, fumarate or L-malate after $24 \mathrm{~h}$ of incubation; moreover, both L-aspartate and fumarate increased L-lactate uptake by $S$. ruminantium more than fourfold, whereas L-malate stimulated uptake more than tenfold. Based on these results, most of the research conducted on the effects of organic acids on rumen fermentation has focused on malate. Both malate and fumarate are key intermediates in the succinate-propionate pathway, which is used by $S$. ruminantium to synthesize succinate and propionate (Martin, 1998). However, compared with the efforts to detail the effects of malate on rumen fermentation, very little research has been conducted to evaluate the effects of fumarate, and most of this work has been conducted with diets containing medium or high proportions of forages (Asanuma et al. 1999; López et al. 1999). As the effects of fumarate could be influenced by the doses of fumarate and the composition of the diet, the objective of the present study was to evaluate the effects of different concentrations of fumarate on the in vitro rumen fermentation of five concentrate feeds (maize, barley, wheat, sorghum and cassava meal). 


\section{Materials and methods}

\section{Substrates and experimental procedure}

Samples of maize, barley, wheat, sorghum and cassava meal were ground through a $1 \mathrm{~mm}$ screen and fermented in vitro with buffered rumen contents. Rumen contents were obtained from four rumen-cannulated Merino sheep fed forage (medium-quality lucerne hay) ad libitum and $300 \mathrm{~g}$ concentrate per d administered in two equal portions at 09.00 and 18.00 hours. Concentrate was based on barley-maize-soyabean meal (39:40:23, by weight on a fresh matter basis). The chemical composition of feeds is given in Table 1. The rumen contents of each sheep were obtained $2 \mathrm{~h}$ after the morning feed of concentrate, mixed and strained through four layers of cheesecloth into an Erlenmeyer flask with an $\mathrm{O}_{2}$-free headspace. Particle-free fluid was mixed with the buffer solution of Goering \& Van Soest (1970) in the proportion $1: 4(\mathrm{v} / \mathrm{v})$ at $39^{\circ} \mathrm{C}$ under continuous flushing with $\mathrm{CO}_{2}$. Samples of $500 \mathrm{mg}$ of each feed were weighed accurately into $125 \mathrm{ml}$ serum bottles (Laboratorios Ovejero S.A., León, Spain). Fumarate (disodium salt; Sigma, Madrid, Spain) was added to achieve final fumarate concentrations of $0,4,7$ and $10 \mathrm{~mm}$. Bottles were prewarmed $\left(39^{\circ} \mathrm{C}\right)$ prior to the addition of $50 \mathrm{ml}$ buffered rumen contents into each bottle under $\mathrm{CO}_{2}$ flushing. Bottles were sealed with rubber stoppers and $\mathrm{Al}$ caps and incubated at $39^{\circ} \mathrm{C}$. The experiment was repeated on four different days, so that each treatment was conducted in quadruplicate.

A total of twenty bottles with substrate (one bottle for each substrate and fumarate concentration) and eight bottles without substrate (two for each fumarate concentration) were incubated each day. Bottles were withdrawn from the incubator $17 \mathrm{~h}$ after inoculation (corresponding to a passage rate from the rumen of 0.06 perh) and total gas production was measured using a pressure transducer. A gas sample was removed from each bottle and stored in a Haemoguard vacutainer (Terumo Europe N.V., Leuven, Belgium) before analysis for $\mathrm{CH}_{4}$ concentration. Bottles were uncapped, the $\mathrm{pH}$ was measured immediately with a $\mathrm{pH}$ meter and the fermentation was stopped by swirling the bottles on ice. Bottles were emptied into centrifuge tubes and centrifuged $\left(600 \mathrm{~g}, 4^{\circ} \mathrm{C}, 10 \mathrm{~min}\right)$ to eliminate feed particles. A portion of the supernatant fraction $(1 \mathrm{ml})$ was added to $1 \mathrm{ml}$ deproteinizing solution (metaphosphoric acid $(100 \mathrm{ml} / \mathrm{l})$ and crotonic acid $(0.6 \mathrm{ml} / \mathrm{l}))$ for volatile fatty acid (VFA) analysis and another $2 \mathrm{ml}$ were added to $2 \mathrm{ml} 0.5 \mathrm{M}-\mathrm{HCl}$ for $\mathrm{NH}_{3}-\mathrm{N}$ analysis. Samples were stored at $-20^{\circ} \mathrm{C}$. A sample of the supernatant fraction $(1.6 \mathrm{ml})$ was added to $0.1 \mathrm{ml}$ deproteinizing solution (metaphosphoric acid, $200 \mathrm{ml} / \mathrm{l})$, centrifuged $\left(15000 \mathrm{~g}, 4^{\circ} \mathrm{C}\right.$, $10 \mathrm{~min}$ ), the $\mathrm{pH}$ adjusted to $7 \cdot 2$ with $1 \mathrm{M}-\mathrm{NaOH}$, and concentrations of L-lactate were analysed by an enzymaticcolorimetric method using a diagnostic kit (Sigma). Finally, the contents of the centrifuge tube were transferred to previously weighed filter crucibles. The residue of incubation was washed with $50 \mathrm{ml}$ hot distilled water, dried at $50^{\circ} \mathrm{C}$ for $48 \mathrm{~h}$ and analysed for ash to calculate the apparent disappearance of organic matter.

\section{Analytical procedures}

$\mathrm{DM}$, ash and $\mathrm{N}$ were determined according to the Association of Official Analytical Chemists (1995). Neutral- and acid-detergent fibre analyses were carried out according to Van Soest et al. (1991) and Goering \& Van Soest (1970) respectively. $\mathrm{NH}_{3}-\mathrm{N}$ concentration was determined by a modified colorimetric method (Weatherburn, 1967). VFA were determined in centrifuged samples $(1 \mathrm{ml})$ by GC as described previously (Carro et al. 1999). $\mathrm{CH}_{4}$ was analysed with a GC (Shimadzu GC 14B; Shimadzu Corporation, Kyoto, Japan) equipped with a flame ionization detector and a column packed with Carboxen 1000 (Supelco, Madrid, Spain). The carrier gas was $\mathrm{He}$ and peaks were identified by comparison with a standard of known composition. The volume of gas produced $(\mathrm{ml})$ was corrected for standard conditions $\left(10^{5} \mathrm{~Pa}, 298 \mathrm{~K}\right)$, and the amount of $\mathrm{CH}_{4}$ produced $(\mu \mathrm{mol})$ was calculated by multiplying the gas produced $(\mu \mathrm{mol})$ by the concentration of $\mathrm{CH}_{4}$ in the analysed sample.

\section{Calculations and statistical analysis}

The amounts of VFA produced were obtained by subtracting the amounts present initially in the incubation medium from those determined at the end of the incubation period. Gas production after $17 \mathrm{~h}$ of incubation was corrected for gas release from endogenous substrates and added fumarate for each inoculum and fumarate concentration. Data for each substrate were analysed as a one-way ANOVA with four concentrations of fumarate $(0,4,7$ and $10 \mathrm{mM})$. The sums of squares were further partitioned by orthogonal

Table 1. Chemical composition ( $\mathrm{g} / \mathrm{kg} \mathrm{DM}$ ) of ingredients of sheep diet and concentrate feeds incubated in vitro

\begin{tabular}{lcccr}
\hline & Organic matter & Crude protein* & Neutral-detergent fibre & Acid-detergent fibre \\
\hline $\begin{array}{l}\text { Diet ingredients } \\
\text { Lucerne hay }\end{array}$ & 912 & 158 & 472 & 301 \\
$\quad$ Concentrate & 916 & 198 & 151 & 47 \\
Cereal grains & & & & 23 \\
$\quad$ Maize & 985 & 90 & 119 & 43 \\
Barley & 974 & 116 & 176 & 29 \\
Wheat & 983 & 103 & 142 & 32 \\
Sorghum & 982 & 21 & 106 & 77 \\
Cassava meal & 951 & & & 189 \\
\hline
\end{tabular}

${ }^{*} \mathrm{~N} \times 6 \cdot 25$. 
polynomial contrast to study linear effects of treatment. Comparisons between treatment means were tested by the least significant difference method. All statistical analyses were performed using the GLM procedure of the Statistical Analysis Systems program (version 6, 1989; SAS Institute Inc., Cary, NC, USA).

\section{Results}

The effects of fumarate on in vitro rumen fermentation of maize, barley, wheat, sorghum and cassava meal are shown in Tables 2, 3, 4, 5 and 6 respectively. For all substrates, final $\mathrm{pH}$ increased linearly $(P<0 \cdot 001)$ as concentrations of fumarate increased, although there were no significant $(P>0.05)$ differences between 7 and $10 \mathrm{~mm}$-fumarate. For maize, $10 \mathrm{~mm}$-fumarate increased $(P<0.05)$ the apparent disappearance of organic matter, but there were no treatment effects $(P>0.05)$ on the apparent disappearance of organic matter for the other substrates.

Whereas the addition of fumarate decreased linearly $(P<0.05)$, the production of $\mathrm{CH}_{4}$ for all substrates, no differences $(P>0.05)$ were found in the total amount of gas produced. There were no differences $(P>0.05)$ in the production of $\mathrm{CH}_{4}$ between fumarate at 7 and $10 \mathrm{~mm}$. With all substrates, fumarate treatment increased $(P<0.001)$ total VFA production linearly, the greatest values being found at 7 and $10 \mathrm{~mm}$-fumarate. Fumarate treatment increased acetate $(P<0.01)$ and propionate $(P<0.001)$ production and decreased $(P<0.001)$ the acetate:propionate value for all substrates. There was no treatment effect $(P>0.05)$ on the production of butyrate and other VFA (calculated as the sum of isobutyrate, isovalerate and valerate) for wheat and sorghum, but the addition of fumarate increased $(P=0 \cdot 040)$ the production of other VFA with maize, and tended $(P=0.057)$ to decrease the production of butyrate for cassava meal. With all substrates, adding increasing concentrations of fumarate to batch cultures decreased $(P<0 \cdot 001)$ the $\mathrm{CH}_{4}(\mu \mathrm{mol})$ :VFA ( $\mu \mathrm{mol})$ value linearly.

There was no significant change $(P>0.05)$ in the amount of $\mathrm{NH}_{3}-\mathrm{N}$ produced with added fumarate for barley, wheat, sorghum and cassava meal, but fumarate tended to decrease $(P=0.089) \quad \mathrm{NH}_{3}-\mathrm{N}$ concentration when maize was incubated. There was no effect $(P>0.05)$ of fumarate on the concentration of L-lactate in the cultures.

In the absence of exogenous substrates, fumarate addition increased $(P<0.001)$ both final $\mathrm{pH}$ and gas production, with no differences $(P>0.05)$ between 7 and $10 \mathrm{~mm}$ (Table 7). Fumarate treatment did not affect $(P>0.05)$ the production of $\mathrm{CH}_{4}$ or $\mathrm{NH}_{3}-\mathrm{N}$ concentration. Acetate, propionate and total VFA production were increased $(P<0.001)$ by the addition of fumarate, and the values of the acetate:propionate and $\mathrm{CH}_{4}$ :VFA ratios were decreased $(P<0.001)$.

\section{Discussion}

In the last few years, several papers have investigated the effects of some dicarboxylic acids, including malate, fumarate and aspartate, on rumen fermentation and digestibility of diet in ruminant animals (Callaway \& Martin, 1996; López et al. 1999; Carro \& Ranilla, 2003), although most of the studies have focused on malate. Few studies have been conducted with fumarate, and in most of them animals were fed roughage alone (Bayaru et al. 2001) or a mixture of roughage and concentrate was used as

Table 2. Influence of concentration of disodium fumarate on in vitro fermentation of maize by mixed rumen micro-organisms in batch culturest

(Mean values for four fermentations)

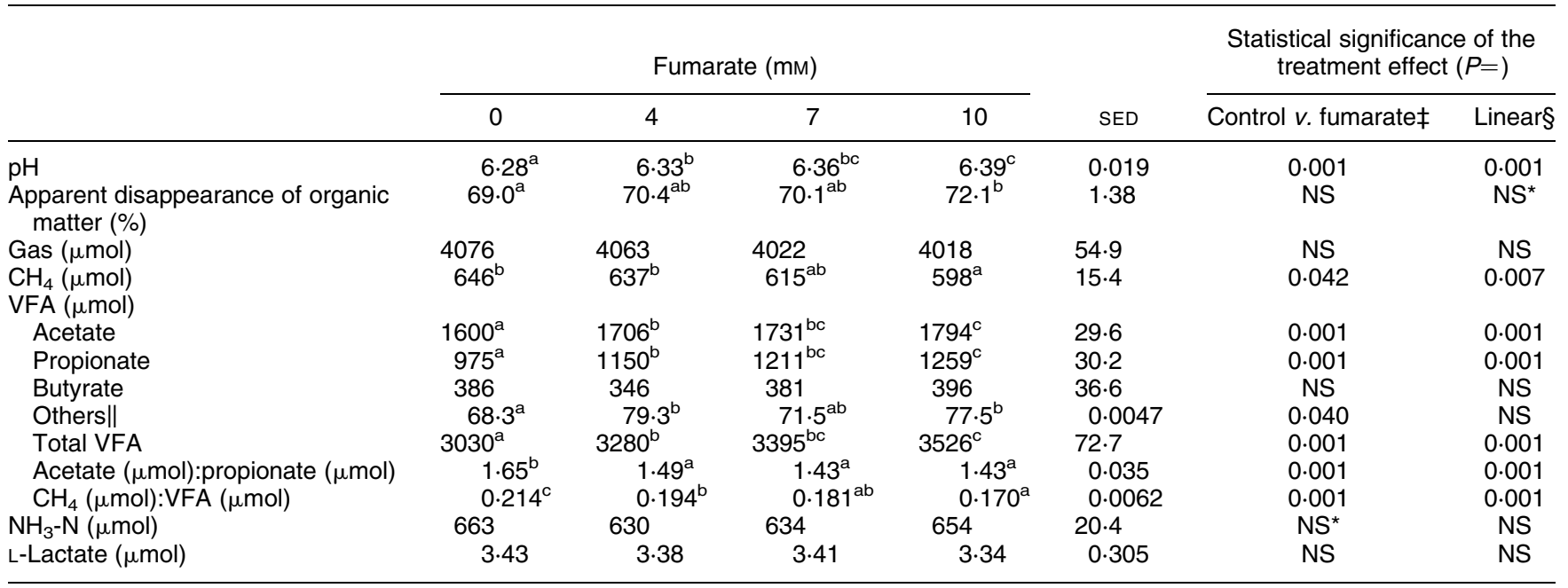

VFA, volatile fatty acid.

a,b,c Mean values within a row with unlike superscript letters were significantly different $(P<0.05)$.

${ }^{*} P<0 \cdot 10$.

$\dagger 50 \mathrm{ml}$ diluted buffered rumen contents were incubated for $17 \mathrm{~h}$ with $500 \mathrm{mg}$ ground maize; for details of diets and procedures, see Table 1 and $\mathrm{p}$. 618 .

$\ddagger$ Orthogonal contrast, control $v$. fumarate: comparison between control and fumarate treatments.

$\S$ Orthogonal polynomials, linear effects of fumarate concentration.

$\|$ Calculated as the sum of isobutyrate, isovalerate and valerate. 
Table 3. Influence of concentration of disodium fumarate on in vitro fermentation of barley by mixed rumen micro-organisms in batch cultures* (Mean values for four fermentations)

\begin{tabular}{|c|c|c|c|c|c|c|c|}
\hline & \multicolumn{4}{|c|}{ Fumarate $(\mathrm{mM})$} & \multirow[b]{2}{*}{ SED } & \multicolumn{2}{|c|}{$\begin{array}{c}\text { Statistical significance of the } \\
\text { treatment effect }(P=)\end{array}$} \\
\hline & 0 & 4 & 7 & 10 & & Control $v$. fumarate $\dagger$ & Linearł \\
\hline $\mathrm{pH}$ & $6 \cdot 38^{a}$ & $6 \cdot 41^{\mathrm{ab}}$ & $6 \cdot 45^{\mathrm{bc}}$ & $6 \cdot 49^{c}$ & 0.020 & 0.002 & 0.001 \\
\hline $\begin{array}{l}\text { Apparent disappearance of organic } \\
\text { matter (\%) }\end{array}$ & $68 \cdot 6$ & $70 \cdot 4$ & $70 \cdot 7$ & $67 \cdot 8$ & $2 \cdot 25$ & NS & NS \\
\hline Gas $(\mu \mathrm{mol})$ & 4246 & 4183 & 4174 & 4174 & $47 \cdot 3$ & NS & NS \\
\hline $\begin{array}{l}\mathrm{CH}_{4}(\mu \mathrm{mol}) \\
\text { VFA }(\mu \mathrm{mol})\end{array}$ & $673^{\mathrm{b}}$ & $657^{\mathrm{a}}$ & $655^{\mathrm{a}}$ & $648^{a}$ & $5 \cdot 86$ & 0.003 & 0.002 \\
\hline Acetate & $1655^{a}$ & $1690^{\mathrm{ab}}$ & $1710^{\mathrm{bc}}$ & $1751^{\mathrm{c}}$ & $19 \cdot 7$ & 0.004 & 0.001 \\
\hline Propionate & $941^{a}$ & $1077^{\mathrm{b}}$ & $1157^{c}$ & $1282^{d}$ & $26 \cdot 6$ & 0.001 & 0.001 \\
\hline Butyrate & 406 & 394 & 387 & 392 & $12 \cdot 3$ & NS & NS \\
\hline Others§ & $96 \cdot 8^{\mathrm{b}}$ & $94 \cdot 8^{\mathrm{ab}}$ & $90 \cdot 8^{\mathrm{ab}}$ & $86 \cdot 3^{\mathrm{a}}$ & $4 \cdot 1$ & NS & 0.024 \\
\hline Total VFA & $3097^{a}$ & $3255^{b}$ & $3345^{c}$ & $3512^{d}$ & 33.5 & 0.001 & 0.001 \\
\hline Acetate $(\mu \mathrm{mol})$ :propionate $(\mu \mathrm{mol})$ & $1.80^{c}$ & $1.59^{b}$ & $1.50^{b}$ & $1.39^{a}$ & 0.048 & 0.001 & 0.001 \\
\hline $\mathrm{CH}_{4}(\mu \mathrm{mol}): \operatorname{VFA}(\mu \mathrm{mol})$ & $0.218^{\mathrm{cd}}$ & $0.202^{b}$ & $0.196^{b}$ & $0 \cdot 185^{a}$ & 0.0016 & 0.001 & 0.001 \\
\hline $\mathrm{NH}_{3}-\mathrm{N}(\mu \mathrm{mol})$ & 831 & 769 & 791 & 831 & 28.4 & NS & NS \\
\hline L-Lactate $(\mu \mathrm{mol})$ & 3.27 & 3.00 & $2 \cdot 85$ & 2.93 & 0.232 & NS & NS \\
\hline
\end{tabular}

VFA, volatile fatty acid.

a,b,c,d Mean values within a row with unlike superscript letters were significantly different $(P<0.05)$.

* $50 \mathrm{ml}$ diluted buffered rumen contents were incubated for $17 \mathrm{~h}$ with $500 \mathrm{mg}$ ground barley; for details of diets and procedures, see Table 1 and $\mathrm{p}$. 618 .

t Orthogonal contrast, control $v$ fumarate: comparison between control and fumarate treatments.

$\ddagger$ Orthogonal polynomials, linear effects of fumarate concentration.

$\S$ Calculated as the sum of isobutyrate, isovalerate and valerate.

substrate for in vitro rumen incubations (Asanuma et al. 1999; López et al. 1999). As the effects of fumarate could be influenced by the composition of the diet, we decided to investigate the effects of fumarate on the in vitro rumen fermentation of several concentrate feeds.

In agreement with the results previously reported by other authors (Callaway \& Martin, 1996; Asanuma et al. 1999; López et al. 1999) with diets of varying composition, the addition of fumarate increased $(P<0.001)$ final $\mathrm{pH}$ with all substrates. As suggested by Callaway \& Martin (1996), malate may act to buffer rumen contents by a dual mechanism of increased lactate utilization and $\mathrm{CO}_{2}$ production by $S$. ruminantium. $S$. ruminantium is a common Gramnegative rumen bacterium that can account for up to $51 \%$ of the total viable bacterial counts in the rumen of animals fed on cereal grains (Caldwell \& Bryant, 1966). In the present experiment, fumarate addition did not affect $(P>0.05)$ L-lactate concentrations.

Table 4. Influence of concentration of disodium fumarate on in vitro fermentation of wheat by mixed rumen micro-organisms in batch cultures* (Mean values for four fermentations)

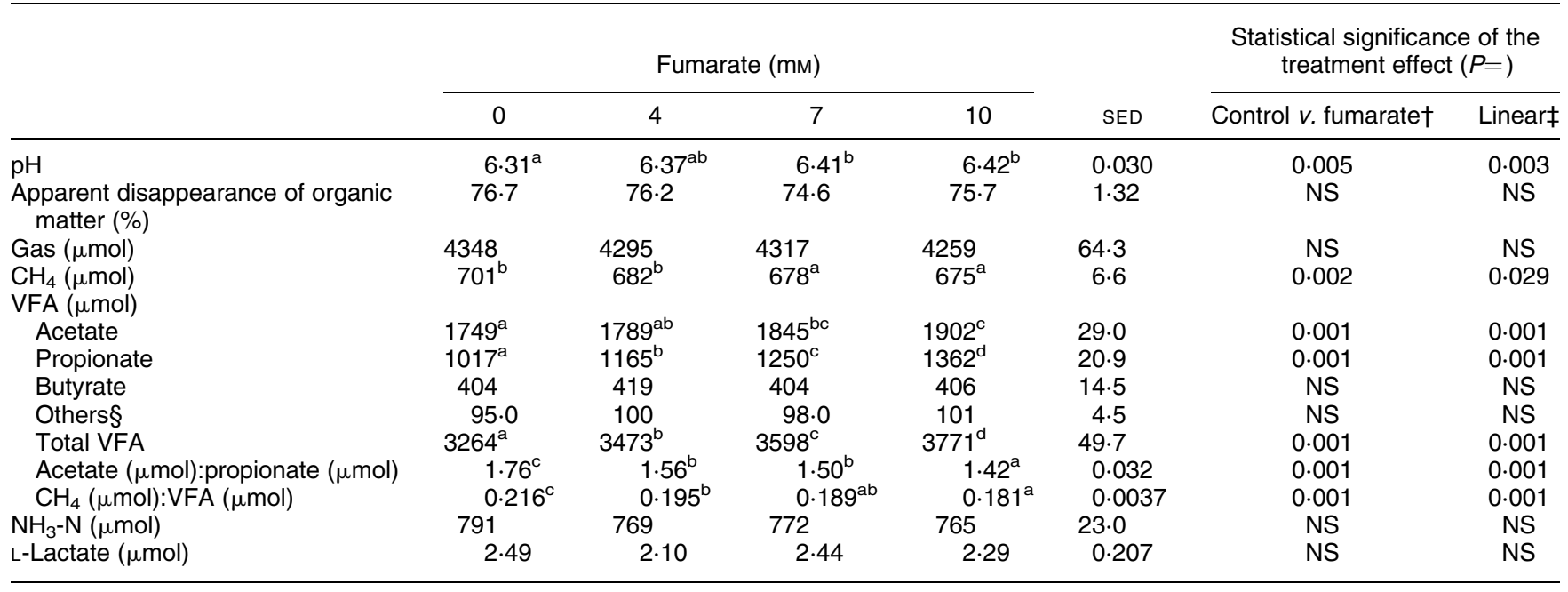

VFA, volatile fatty acid.

a,b,c,d Mean values within a row with unlike superscript letters were significantly different $(P<0.05)$

* $50 \mathrm{ml}$ diluted buffered rumen contents were incubated for $17 \mathrm{~h}$ with $500 \mathrm{mg}$ ground wheat; for details of diets and procedures, see Table 1 and p. 618 .

† Orthogonal contrast, control $v$. fumarate: comparison between control and fumarate treatments.

$\ddagger$ Orthogonal polynomials, linear effects of fumarate concentration.

$\S$ Calculated as the sum of isobutyrate, isovalerate and valerate. 
Table 5. Influence of concentration of disodium fumarate on in vitro fermentation of sorghum by mixed rumen micro-organisms in batch cultures*

(Mean values for four fermentations)

\begin{tabular}{|c|c|c|c|c|c|c|c|}
\hline & \multicolumn{4}{|c|}{ Fumarate (mM) } & \multirow[b]{2}{*}{ SED } & \multicolumn{2}{|c|}{$\begin{array}{l}\text { Statistical significance of the } \\
\text { treatment effect }(P=)\end{array}$} \\
\hline & 0 & 4 & 7 & 10 & & Control v. fumarate $\dagger$ & Linearf \\
\hline $\mathrm{pH}$ & $6 \cdot 39^{a}$ & $6 \cdot 46^{\mathrm{b}}$ & $6 \cdot 47^{\mathrm{b}}$ & $6 \cdot 50^{b}$ & 0.021 & 0.001 & 0.001 \\
\hline $\begin{array}{l}\text { Apparent disappearance of organic } \\
\text { matter (\%) }\end{array}$ & $59 \cdot 5$ & $59 \cdot 0$ & $58 \cdot 3$ & $59 \cdot 6$ & 1.36 & NS & NS \\
\hline Gas ( $\mu \mathrm{mol})$ & 3813 & 3719 & 3768 & 3688 & 63.4 & NS & NS \\
\hline $\begin{array}{l}\mathrm{CH}_{4}(\mu \mathrm{mol}) \\
\text { VFA }(\mu \mathrm{mol})\end{array}$ & $637^{\mathrm{b}}$ & $615^{\mathrm{b}}$ & $607^{\mathrm{ab}}$ & $605^{a}$ & 13.9 & 0.035 & 0.050 \\
\hline Acetate & $1469^{a}$ & $1489^{a}$ & $1563^{b}$ & $1594^{\mathrm{b}}$ & $26 \cdot 6$ & 0.005 & 0.001 \\
\hline Propionate & $908^{\mathrm{a}}$ & $1052^{b}$ & $1110^{\mathrm{c}}$ & $1166^{\mathrm{d}}$ & $18 \cdot 0$ & 0.001 & 0.001 \\
\hline Butyrate & 347 & 345 & 328 & 331 & $10 \cdot 3$ & NS & NS \\
\hline Others§ & $75 \cdot 0$ & $86 \cdot 7$ & $72 \cdot 5$ & $67 \cdot 0$ & $8 \cdot 8$ & NS & NS \\
\hline Total VFA & $2791^{\mathrm{a}}$ & $2972^{b}$ & $3074^{\mathrm{c}}$ & $3158^{\mathrm{C}}$ & $38 \cdot 3$ & 0.001 & 0.001 \\
\hline Acetate $(\mu \mathrm{mol})$ :propionate $(\mu \mathrm{mol})$ & $1 \cdot 66^{\mathrm{b}}$ & $1.43^{\mathrm{a}}$ & $1.42^{\mathrm{a}}$ & $1 \cdot 38^{\mathrm{a}}$ & 0.031 & 0.001 & 0.001 \\
\hline $\mathrm{CH}_{4}(\mu \mathrm{mol}): \mathrm{VFA}(\mu \mathrm{mol})$ & $0.229^{c}$ & $0.207^{b}$ & $0 \cdot 197^{\mathrm{ab}}$ & $0 \cdot 193^{\mathrm{a}}$ & 0.0051 & 0.001 & 0.001 \\
\hline $\mathrm{NH}_{3}-\mathrm{N}(\mu \mathrm{mol})$ & 761 & 718 & 725 & 729 & $24 \cdot 8$ & NS & NS \\
\hline L-Lactate $(\mu \mathrm{mol})$ & 1.78 & 1.75 & 1.60 & 1.71 & 0.080 & NS & NS \\
\hline
\end{tabular}

VFA, volatile fatty acid.

a,b,c,d Mean values within a row with unlike superscript letters were significantly different $(P<0.05)$

* $50 \mathrm{ml}$ dilute buffered rumen contents were incubated for $17 \mathrm{~h}$ with $500 \mathrm{mg}$ ground sorghum; for details of diets and procedures, see Table 1 and $\mathrm{p}$. 618 .

† Orthogonal contrast, control $v$. fumarate: comparison between control and fumarate treatments.

$\ddagger$ Orthogonal polynomials, linear effects of fumarate concentration.

$\S$ Calculated as the sum of isobutyrate, isovalerate and valerate.

Nisbet \& Martin (1993) showed that the growth of $S$. ruminantium in a medium that contained DL-lactate was stimulated approximately twofold by $10 \mathrm{~mm}$-fumarate after $24 \mathrm{~h}$ of incubation. Fumarate is a key intermediate in the succinate-propionate pathway and is used by $S$. ruminantium to form succinate and propionate (Martin, 1998). In the present study, supplementation with fumarate increased $(P<0.001)$ propionate production with all substrates by about $61 \mu \mathrm{mol} / 100 \mu \mathrm{mol}$ fumarate added (mean value for all substrates and concentrations of fumarate). The conversion of fumarate to propionate for maize was 86,66 and $56 \%$ of added fumarate for 4,7 and $10 \mathrm{~mm}$ treatments respectively (Table 2). Recoveries with barley, wheat and sorghum (Tables 3,4 and 5) were lower for

Table 6. Influence of concentration of disodium fumarate on in vitro fermentation of cassava meal by mixed rumen micro-organisms in batch cultures

(Mean values for four fermentations)

\begin{tabular}{|c|c|c|c|c|c|c|c|}
\hline & \multicolumn{4}{|c|}{ Fumarate (mM) } & \multirow[b]{2}{*}{ SED } & \multicolumn{2}{|c|}{$\begin{array}{c}\text { Statistical significance of the } \\
\text { treatment effect }(P=)\end{array}$} \\
\hline & 0 & 4 & 7 & 10 & & Control $v$. fumarateł & Linear§ \\
\hline $\mathrm{pH}$ & $6 \cdot 45^{\mathrm{a}}$ & $6 \cdot 50^{\mathrm{b}}$ & $6 \cdot 51^{b c}$ & $6.53^{\mathrm{c}}$ & 0.012 & 0.001 & 0.001 \\
\hline $\begin{array}{l}\text { Apparent disappearance of organic } \\
\text { matter (\%) }\end{array}$ & $68 \cdot 4$ & $69 \cdot 0$ & $69 \cdot 2$ & $67 \cdot 5$ & $1 \cdot 88$ & NS & NS \\
\hline Gas ( $\mu \mathrm{mol})$ & 4388 & 4393 & 4371 & 4335 & $46 \cdot 4$ & NS & NS \\
\hline $\mathrm{CH}_{4}(\mu \mathrm{mol})$ & $614^{\mathrm{b}}$ & $603^{\mathrm{ab}}$ & $591^{a}$ & $590^{\mathrm{a}}$ & $9 \cdot 3$ & 0.029 & 0.017 \\
\hline \multicolumn{8}{|l|}{ VFA ( $(\mu \mathrm{mol})$} \\
\hline Acetate & $1406^{a}$ & $1458^{\mathrm{ab}}$ & $1492^{b c}$ & $1542^{c}$ & $32 \cdot 8$ & 0.008 & 0.002 \\
\hline Propionate & $884^{\mathrm{a}}$ & $988^{\mathrm{b}}$ & $1028^{\mathrm{bc}}$ & $1096^{c}$ & 31.6 & 0.001 & 0.001 \\
\hline Butyrate & 379 & 348 & 359 & 351 & $15 \cdot 0$ & $\mathrm{NS}^{*}$ & NS \\
\hline Others\| & $20 \cdot 8$ & $18 \cdot 0$ & $18 \cdot 8$ & 18.5 & $2 \cdot 24$ & NS & NS \\
\hline Total VFA & $2690^{\mathrm{a}}$ & $2793^{\mathrm{ab}}$ & $2898^{\mathrm{bc}}$ & $3007^{c}$ & 57.6 & 0.002 & 0.001 \\
\hline Acetate $(\mu \mathrm{mol})$ :propionate $(\mu \mathrm{mol})$ & $1.65^{\mathrm{b}}$ & $1.51^{\mathrm{a}}$ & $1.47^{\mathrm{a}}$ & $1.46^{\mathrm{a}}$ & 0.046 & 0.002 & 0.003 \\
\hline $\mathrm{CH}_{4}(\mu \mathrm{mol}): \operatorname{VFA}(\mu \mathrm{mol})$ & $0.231^{\mathrm{c}}$ & $0.217^{b}$ & $0.205^{\mathrm{a}}$ & $0 \cdot 197^{\mathrm{a}}$ & 0.045 & 0.001 & 0.001 \\
\hline $\mathrm{NH}_{3}-\mathrm{N}(\mu \mathrm{mol})$ & 125 & 128 & 122 & 127 & $8 \cdot 4$ & NS & NS \\
\hline L-Lactate $(\mu \mathrm{mol})$ & 2.93 & 3.04 & 2.85 & 3.05 & 0.210 & NS & NS \\
\hline
\end{tabular}

VFA, volatile fatty acid.

a,b,c Mean values within a row with unlike superscript letters were significantly different $(P<0.05)$.

${ }^{*} P<0 \cdot 10$.

$\dagger 50 \mathrm{ml}$ diluted buffered rumen contents were incubated for $17 \mathrm{~h}$ with $500 \mathrm{mg}$ ground cassava meal; for details of diets and procedures, see Table 1 and $\mathrm{p}$. 618 .

$\ddagger$ Orthogonal contrast, control $v$. fumarate: comparison between control and fumarate treatments.

$\S$ Orthogonal polynomials, linear effects of fumarate concentration.

\|C Calculated as the sum of isobutyrate, isovalerate and valerate. 
Table 7. Influence of concentration of disodium fumarate on fermentation by mixed ruminal micro-organisms in the absence of added substrates in batch cultures*

(Mean values for eight fermentations)

\begin{tabular}{|c|c|c|c|c|c|c|c|}
\hline & \multicolumn{4}{|c|}{ Fumarate (mM) } & \multirow[b]{2}{*}{ SED } & \multicolumn{2}{|c|}{$\begin{array}{c}\text { Statistical significance of the } \\
\text { treatment effect }(P=)\end{array}$} \\
\hline & 0 & 4 & 7 & 10 & & Control $v$. fumarate $\dagger$ & Linearł \\
\hline $\mathrm{pH}$ & $6 \cdot 81^{a}$ & $6 \cdot 83^{b}$ & $6 \cdot 86^{c}$ & $6 \cdot 86^{c}$ & 0.010 & 0.001 & 0.001 \\
\hline Gas ( $\mu \mathrm{mol})$ & $1125^{\mathrm{a}}$ & $1205^{b}$ & $1228^{b c}$ & $1268^{c}$ & $31 \cdot 7$ & 0.001 & 0.001 \\
\hline $\begin{array}{l}\mathrm{CH}_{4}(\mu \mathrm{mol}) \\
\text { VFA }(\mu \mathrm{mol})\end{array}$ & 205 & 201 & 201 & 208 & $5 \cdot 8$ & NS & NS \\
\hline Propionate & $98 \cdot 4^{\mathrm{a}}$ & $224^{\mathrm{b}}$ & $304^{c}$ & $384^{d}$ & 6.4 & 0.001 & 0.001 \\
\hline Butyrate & $81 \cdot 5$ & $82 \cdot 0$ & $77 \cdot 3$ & 76.9 & $4 \cdot 6$ & NS & NS \\
\hline Others§ & $63 \cdot 1$ & $65 \cdot 8$ & 63.9 & $62 \cdot 8$ & $3 \cdot 7$ & NS & NS \\
\hline Total VFA & $686^{a}$ & $893^{b}$ & $1012^{C}$ & $1122^{d}$ & $22 \cdot 2$ & 0.001 & 0.001 \\
\hline Acetate ( $\mu \mathrm{mol})$ :propionate ( $\mu \mathrm{mol})$ & $4 \cdot 86^{b}$ & $2 \cdot 35^{a}$ & $1 \cdot 86^{\mathrm{a}}$ & $1.55^{\mathrm{a}}$ & $0 \cdot 828$ & 0.001 & 0.001 \\
\hline $\mathrm{CH}_{4}(\mu \mathrm{mol}):$ VFA $(\mu \mathrm{mol})$ & $0.320^{c}$ & $0 \cdot 230^{\mathrm{b}}$ & $0.202^{a}$ & $0.189^{a}$ & 0.0189 & 0.001 & 0.001 \\
\hline $\mathrm{NH}_{3}-\mathrm{N}(\mu \mathrm{mol})$ & 1071 & 1118 & 1093 & 1056 & $32 \cdot 1$ & NS & NS \\
\hline L-Lactate ( $\mu \mathrm{mol})$ & $1 \cdot 73$ & 1.69 & 1.68 & 1.76 & $0 \cdot 119$ & NS & NS \\
\hline
\end{tabular}

VFA, volatile fatty acid.

a,b,c,d Mean values within a row with unlike superscript letters were significantly different $(P<0.05)$.

* $50 \mathrm{ml}$ diluted buffered rumen contents were incubated for $17 \mathrm{~h}$; for details of diets and procedures, see Table 1 and p. 618 .

† Orthogonal contrast, control $v$. fumarate: comparison between control and fumarate treatments.

$\ddagger$ Orthogonal polynomials, linear effects of fumarate concentration.

$\S$ Calculated as the sum of isobutyrate, isovalerate and valerate.

4 mM-fumarate (mean value $70 \%$ ), but similar to those for maize at 7 and $10 \mathrm{~mm}$ (61 and $62 \%$ respectively). Conversely, cassava meal gave lower values: 51, 40 and $42 \%$ for 4,7 and $10 \mathrm{~mm}$-fumarate respectively (Table 6). In general, our present values are lower than the 85 and $79 \%$ reported by López et al. (1999), when fumarate was added to batch cultures containing a forage diet $(500 \mathrm{~g} / \mathrm{kg})$ at 5 and $10 \mathrm{~mm}$ respectively, but are in reasonable agreement with the values of 60 and $77 \%$ reported by Callaway \& Martin (1996), when fumarate was added to batch cultures with cracked maize at 4 and $12 \mathrm{~mm}$ respectively. These results indicate that fumarate utilization in vitro may depend on the fermented substrate.

Fumarate can be converted into propionate and acetate following different pathways (Demeyer \& Henderickx, 1967). In the present experiment, the addition of fumarate increased $(P<0.01)$ acetate production with all substrates. Maize gave the greatest conversion of fumarate to acetate (52, 37 and $38 \%$ for 4,7 and $10 \mathrm{~mm}$ treatments respectively), whereas the other four substrates showed considerably lower recoveries (mean values 18, 23 and $25 \%$ for 4 , 7 and $10 \mathrm{~mm}$-fumarate respectively). Calculated recoveries of fumarate as acetate plus propionate were always $<100 \%$ for barley, wheat, sorghum and cassava meal (mean values 83,79 and $82 \%$ for 4,7 and $10 \mathrm{~mm}$ treatments respectively); in contrast, recoveries for maize were 138, 103 and $94 \%$ for 4,7 and $10 \mathrm{~mm}$-fumarate respectively. These results indicate that fumarate at $4 \mathrm{~mm}$, and possibly at $7 \mathrm{mM}$, stimulated the in vitro fermentation of maize. The tendency to lower $(P=0.089) \mathrm{NH}_{3}-\mathrm{N}$ concentrations in the cultures observed when maize (Table 2) was incubated with fumarate could be due to a greater utilization by rumen microbes. On the other hand, the observed increases in acetate and propionate production with the other four substrates could stem from fumarate fermentation itself. To test this possibility, incubations in the absence of incubated substrates were conducted. In the absence of exogenous substrates, fumarate recoveries as acetate plus propionate were 100, 92 and $87 \%$ for 4 , 7 and $10 \mathrm{~mm}$ concentrations respectively, which would indicate that $4 \mathrm{~mm}$-fumarate was completely fermented after $17 \mathrm{~h}$. The lower recoveries observed for 7 and $10 \mathrm{~mm}$-fumarate could be due to the accumulation of other final products, such as succinate.

The conversion of glucose to acetate, propionate and butyrate in the rumen results in an overall net release of reducing power. Much of this is used by methanogenic archaea to reduce $\mathrm{CO}_{2}$ to $\mathrm{CH}_{4}$, but $\mathrm{H}$ can also be used as a substrate in fumarate reduction (Russell \& Wallace, 1997). As $\mathrm{H}$ is used to reduce fumarate, there is a decrease in the availability of $\mathrm{H}$ for methanogenesis in the rumen, which could decrease $\mathrm{CH}_{4}$ production. Although fumarate significantly decreased $(P<0.05) \mathrm{CH}_{4}$ production with all substrates, the observed decrease was lower than that found by other authors. Bayaru et al. (2001) reported that fumaric acid supplementation $(20 \mathrm{~g} / \mathrm{kg}$ diet DM) produced a $23.0 \%$ decrease in $\mathrm{CH}_{4}$ production in steers fed sorghum silage as the only feed, and López et al. (1999) found that adding disodium fumarate $(7.35 \mathrm{~mm}$-fumarate) to semicontinuous fermenters fed a mixed diet $(500 \mathrm{~g}$ grass hay/ $\mathrm{kg}$ feed) decreased $\mathrm{CH}_{4}$ production by $17 \%$. $\mathrm{CH}_{4}$ production in our present experiment was reduced by $2 \cdot 3$, 3.8 and $4.8 \%$ for 4,7 and $10 \mathrm{~mm}$-fumarate respectively (mean values for all substrates), which indicates that fumarate would be impractical as a means of reducing $\mathrm{CH}_{4}$ emissions in vivo (López et al. 1999). The observed reduction in $\mathrm{CH}_{4}$ production is consistent with the lower response found by other authors when concentrate feeds were incubated in vitro with rumen contents; thus, Asanuma et al. (1999) reported that the addition of $20 \mathrm{~mm}$-fumarate to batch cultures containing a concentrate diet $(750 \mathrm{~g} / \mathrm{kg})$ reduced $\mathrm{CH}_{4}$ production by $5.3 \%$ after $6 \mathrm{~h}$ 
of incubation, and Callaway \& Martin (1996) found a 3.9 and $2.6 \%$ decrease in $\mathrm{CH}_{4}$ production when 4 and $12 \mathrm{mM}$-fumarate were added to in vitro fermentations of cracked maize respectively. From these results, it seems that the effect of fumarate on $\mathrm{CH}_{4}$ production in the rumen may largely depend on the nature of the fermented substrate, as fumarate could be more effective in decreasing $\mathrm{CH}_{4}$ production with forage-based diets than with high-concentrate diets.

$\mathrm{CH}_{4}$ production is affected by many factors, such as the type of diet and the rumen $\mathrm{pH}$; thus, fewer methanogens have been detected in the rumen of concentrate-fed animals than in the rumen of forage-fed ones (Demeyer \& Fievez, 2000), and $\mathrm{pH}$ values in our present incubations were $<6.5$, a value below which $\mathrm{CH}_{4}$ production decreases dramatically (Van Kessel \& Russell, 1996). As a consequence of the changes observed in the production of both $\mathrm{CH}_{4}$ and VFA, the value of $\mathrm{CH}_{4}$ ( $\left.\mu \mathrm{mol}\right)$ : VFA ( $\left.\mu \mathrm{mol}\right)$ decreased linearly as concentrations of fumarate increased for all substrates. If these results are confirmed in vivo, the use of fumarate as a feed additive in ruminant animals fed highconcentrate diets could increase the amount of energy obtained in the rumen per unit of fermented substrate.

The results of the present study suggest that fumarate has a beneficial effect on in vitro rumen fermentation of concentrate feeds by increasing final $\mathrm{pH}$ and the production of acetate and propionate, and by decreasing $\mathrm{CH}_{4}$ production. Some of these effects are dose-dependent, but in general, no beneficial effects of 10 compared with $7 \mathrm{~mm}$-fumarate were observed. The greater response found for maize in comparison with the other concentrate feeds might indicate that fumarate utilization in vitro could depend on the fermented substrate. If the effects observed in the present experiment are confirmed in vivo with animals fed high-concentrate diets, fumarate could provide an alternative to currently used feed antibiotic growth promoters. In any case, more studies with diets of different composition are required to assess the dietary conditions that influence the effectiveness of fumarate and its long-term effects.

\section{Acknowledgements}

The authors wish to acknowledge the financial support received from the CICYT (Project AGL2001-0130) and Junta de Castilla y León (Project LE62/03). M. J. R gratefully acknowledges receipt of a research contract from the Ministerio de Ciencia y Tecnología of Spain (Programa Ramón y Cajal).

\section{References}

Asanuma N, Iwamoto M \& Hino T (1999) Effect of the addition of fumarate on methane production by ruminal microorganisms in vitro. J Dairy Sci 82, 780-787.

Association of Official Analytical Chemists (1995) Official Methods of Analysis, 16th ed., chapter 4, p. 13. Arlington, VA: AOAC
Bayaru E, Syuhei K \& Toshihiko K, et al. (2001) Effect of fumaric acid on methane production, rumen fermentation and digestibility of cattle fed roughage alone. Anim Sci J 72, 139-146.

Caldwell DR \& Bryant MP (1966) Medium without rumen fluid for non-selective enumeration and isolation of rumen bacteria. Appl Microbiol 14, 794-801.

Callaway TR \& Martin SA (1996) Effects of organic acid and monensin treatment on in vitro mixed ruminal microorganism fermentation of cracked corn. J Anim Sci 74, 1982-1989.

Carro MD, López S, Valdés C \& Ovejero FJ (1999) Effect of DL-malate on mixed ruminal microorganism fermentation using the rumen simulation technique (RUSITEC). Anim Feed Sci Technol 79, 279-288.

Carro MD \& Ranilla MJ (2003) Effect of the addition of malate on in vitro rumen fermentation of cereal grains. Br J Nutr 89, $181-188$.

Carro MD, Valdés C, Ranilla MJ \& González JS (2000) Effect of forage to concentrate ratio in the diet on ruminal fermentation and digesta flow kinetics in sheep. Anim Sci 70, $127-134$.

Demeyer DI \& Henderickx MK (1967) Competitive inhibition of in vitro methane production by mixed rumen bacteria. Arch Int Physiol Biochim 75, 157-159.

Demeyer DI \& Fievez V (2000) Ruminants et environnement: la méthanogenèse (Ruminants and environment: methanogenesis). Ann Zootech 49, 95-112.

Goering MK \& Van Soest PJ (1970) Forage Fiber Analysis (Apparatus, Reagents, Procedures and Some Applications) Agricultural Handbook, no. 379. Washington, DC: ARS, USDA.

López S, Valdés C, Newbold CJ \& Wallace RJ (1999) Influence of sodium fumarate addition on rumen fermentation in vitro. Br J Nutr 81, 59-64.

Martin SA (1998) Manipulation of ruminal fermentation with organic acids: a review. J Anim Sci 76, 3123-3132.

Mould FL (1988) Associative effects of feeds. In Feed Science World. Animal Science, B4, pp. 279-292 [ER Ørskov, editor]. Amsterdam: Elsevier Science Publishers BV.

Newbold CJ, Wallace RJ \& McIntosh FM (1996) Mode of action of the yeast Saccharomyces cerevisiae as a feed additive for ruminants. Br J Nutr 76, 249-261.

Nisbet DJ \& Martin SA (1990) Effect of dicarboxylic acids and Aspergillus oryzae fermentation extract on lactate uptake by the ruminal bacterium Selenomonas ruminantium. Appl Environ Microbiol 26, 133-136.

Nisbet DJ \& Martin SA (1993) Effects of fumarate, L-malate, and an Aspergillus oryzae fermentation extract on D-lactate utilization by the ruminal bacterium Selenomonas ruminantium. Curr Microbiol 26, 133-136.

Russell JB \& Wallace RJ (1997) Energy consuming and yielding mechanisms. In The Rumen Microbial Ecosystem, 2nd ed. pp. 246-282 [PN Hobson and CS Stewart, editors]. London: Chapman \& Hall.

Van Kessel JAS \& Russell JB (1996) The effect of pH on ruminal methanogenesis. FEMS Microbiol Ecol 20, 205-210.

Van Soest PJ, Robertson JB \& Lewis BA (1991) Methods for dietary fiber, neutral detergent fiber, and nonstarch polysaccharides in relation to animal nutrition. $J$ Dairy $S c i \mathbf{7 4}$, 3583-3597.

Weatherburn MW (1967) Phenol-hypochlorite reaction for determination of ammonia. Anal Chem 39, 971-974. 